\title{
Wave regime characterization in the northern sector of Patos Lagoon, Rio Grande do Sul, Brazil
}

\author{
Chayonn Marinho ${ }^{1 *}{ }^{\oplus}$, Jorge Arigony Neto ${ }^{1,2}{ }^{\circledR}$, João Luiz Nicolodi ${ }^{\circledR}$, Natália Lemke ${ }^{3}$, \\ José Antônio Scotti Fontoura ${ }^{4}$
}

\footnotetext{
1 Universidade Federal do Rio Grande -Instituto de Oceanografia (Av. Itália, Km. 8, s/n., , Bairro Carreiros, Rio Grande - Caixa Postal: 474 - 96.201-900 - RS - Brazil)

${ }^{2}$ Macquarie University - Departament of Environmental Sciences (Level 4 - 12 Wally's WalkNorth Ryde - Sydney - Australia)

${ }^{3}$ Universidade Federal do Rio Grande - Instituto de Matemática, Estatística e Física (Campus Carreiros - Av. Itália km 8 Bairro Carreiros - 96201-900 - Rio Grande - RS -Brazil

${ }^{4}$ Universidade Federal do Rio Grande - Laboratório de Engenharia Costeira (Av. Itália, s/n - km - Campus Carreiros - Rio Grande - 96203-900 - RS - Brazil)

*Corresponding author: chayonn@hotmail.com
}

\section{Abstract}

This paper describes wave prediction results for Patos Lagoon's northern sector through numerical modeling using Delft3D software. ERA-Interim satellite reanalysis data of wind intensity and direction were used as inputs to force the hydrodynamic model. For SWAN calibration and validation in the study region, wave parameters were used. These parameters were acquired in situ by a directional waverider buoy. Statistical data showed the good performance of the model, albeit with a tendency to overestimate significant wave height and underestimate peak period and propagation direction. Once validated, wave parameters for five points at different depths were obtained during the four seasons of the year between 2017 and 2018. In general, it was observed that the largest ripples come from the S and SSW directions and occurred during spring at the deepest point under wind conditions exceeding $10 \mathrm{~m} \mathrm{~s}^{-1}$. Ripples up to $0.30 \mathrm{~m}$ account for $77.9 \%$ at the shallowest point and $65.7 \%$ at the deepest point. Thus, the study area was classified as low energy and characterized by small, high-frequency, short-period ripples strongly influenced and determined by the local depth because larger ripples are always observed in the deepest locations, giving the lagoon a characteristic of depth-limited ripples. The results obtained here have the potential to contribute to territorial management of the region, with emphasis on the Integral Protection Conservation Unit located in the study area (Itapuã State Park) and on the development and safety of the important, heavily used navigation route that connects Rio Grande Port to the state capital, Porto Alegre.

Descriptors: Wave modeling; SWAN; wave regime in Patos Lagoon.

\section{INTRODUCTION}

Wave climate knowledge of a particular region is critical to understanding local hydrodynamics, sediment transportation, and coastal morphology. This fact becomes essential for building a strategic vision against scenarios of global warming, sea-level rise, and coastal erosion (Nicolodi \& Pettermann,

Submitted on: 21/October/2019

Approved on: 28/ July/2020

Associate Editor: Marcelo Dottori

Editor: Rubens M. Lopes
2011). Specifically, in Patos Lagoon, orientation changes of its margins concerning wind patterns are accompanied by erosion or deposition processes (Villwock, 1986), developing bays in erosional profiles and sandspits in depositional situations.

Based on wave models and global ocean/ atmosphere reanalysis, many efforts have been made in recent decades to generate a consistent dataset to define wave climate. Several global reanalysis have been published lately with sharper spatial resolution and improved process approximation methods (Rodríguez et al., 2018). 
A considerable portion of the energy transferred from the atmosphere to oceans, lakes, and lagoons is carried in waves (Paes-Leme et al., 2008), and windgenerated waves are considered the dominant force in coastal hydrodynamics and morphodynamics (Rocha et al., 2012). The wave climate characterization of a region is determined through the statistical pattern of descriptive parameters, such as significant wave height, peak period, and propagation direction. Another factor that directly contributes to this characterization is the climate, location of atmospheric systems, and prevailing wind regime.

Although there is knowledge about the current subject in Brazil, the systematic monitoring of variables such as waves and tides is still very recent (Rodríguez et al., 2018). There are few data on wave measurements, especially in the form of a more extended and more reliable time series. Three methods can obtain wave measurement: visual estimates, in situ techniques, and remotely operating sensors. Visual estimates have been widely used until recently, especially in small projects, and the data have been validated by several researchers (Jardine, 1979; Bryant, 1979; Guedes Soares, 1986; Plant \& Griggs, 1992). In situ instruments are used to acquire time series of three-dimensional independent wave parameters and should be placed on the surface, such as a directional waverider buoy, or fixed below the surface, such as an acoustic Doppler current profiler (ADCP) (Holthuijsen, 2007). Remote sensing measurements, or the use of altimeter radar onboard satellites, are widely used in ocean bathymetry, topography, and wave measurement. Specifically, in the case of waves, altimeter radars measure the height of the satellite relative to the sea surface, so the radar emits a pulse that first reflects the wave's crest and then its pit. The difference between pulse emission and pulse reception is used to calculate the wavelength. Although this type of method's resolution and accuracy are lower than those of in situ instruments, it has the advantage of greater area coverage and is used in global model validation processes (Sánchez et al., 2018).

Through the advancement of computing, numerical models have been widely improved and used throughout the world. Attention should be paid to the need to provide the model with highresolution data and a set of physical parameters to calibrate for each study region. One of the most widely used models in determining wave patterns around the world is the SWAN (Simulating Waves Nearshore) model, which has the great advantage of its versatility because it can be applied to large open coastal areas or confined areas such as bays and estuaries. Numerous researchers have used SWAN for wave modeling in sheltered environments, such as the Black Sea (Akpinar et al., 2012; Rusu, 2016; Rusu et al., 2014; Van Vleder \& Akpinar, 2015), Spanish coast (Pallares et al., 2014) and Brazil (Nicolodi et al., 2013).

Matos et al. (2017) report results from the application of the numeric model SWAN with comparative analysis among measures from modeling and obtained during a field campaign, carried out between 2010 and 2012, on the northern coast of Rio Grande do Norte (Northeast of Brazil). The statistical results of the model validation showed a tendency to overestimate wave height and underestimate peak period. Regarding the direction of propagation of the waves, very distinct results were observed between the modeled and measured data. Cassiano et al. (2012) performed a ten-year wave simulation to obtain the typical wave climate in Santos beach using SWAN. Wave data were collected in the middle of the Santos Bay with an ADCP for six months. These data were used to understanding the wave climate and validated wave modeling. Guimarães et al. (2015) studied the extreme acceleration of waves during storm events at Tramandaí beach, Rio Grande do Sul, Brazil. To do so, they used numerical simulation, combining Wave Watch III, SWAN, and SWASH models to achieve a precise and computationally feasible simulation of waves at different times and spatial scales, from the formation process in deep water to the total dissipation of energy in the area flood. It was discovered that the empirical models lead to the systematic overestimation of the runup results.

Specifically, in Patos Lagoon, some studies such as those of, Lemke et al. (2017)and Lemke et al. (2018) can be cited. Despite some recent studies published in Patos Lagoon, according to Fontoura et al. (2015), until 2015, there were no records of detailed studies on the wave regime in Patos Lagoon, and studies in this area are scarce. Also, no work has been performed in the northern sector of the lagoon. Patos Lagoon is a large and heavily navigated coastal lagoon that connects the Rio Grande Port to the Rio Grande do 
Sul state capital of Porto Alegre, thus a valid local hydrodynamic model is in high demand.

Lemke et al. (2018) conducted a detailed study of the wind regime in Patos Lagoon through linear correlations between the European and North American reanalysis models (i.e., ECMWF and NCEP/ NCAR) at different lagoon points and measurement stations. Thus, it was concluded that there is no significant spatial variation in the lagoon wind fields intensity and direction between the four analyzed points of the European Center for Medium-Range Weather Forecasts (ECMWF) model due to the excellent linear correlations. However, some variation can be expected when comparing results between models due to the distance between analysis sites. This study indicated that the models are valid for the study location.

A calibrated and validated wave model, where it is possible to understand the wind patterns acting on the coastal dynamics and to make new data available for the study region, is likely to improve navigation safety, beach safety, and coastal erosion, addressing part of the challenges of coastal management. Thus, the objective of the present study is to determine the wave regime in the northern sector of Patos Lagoon using the SWAN numerical model.

\section{MATERIAL AND METHODS}

\section{Study Area}

Patos Lagoon is located between $30^{\circ} \mathrm{S}$ and $32^{\circ} \mathrm{S}$, in the state of Rio Grande do Sul, and is the largest coastal lagoon in Brazil, measuring approximately $240 \mathrm{~km}$ long and $40 \mathrm{~km}$ wide average. Despite its vast extent, it is a shallow water body, with an average depth of 6 meters, connected to the Atlantic Ocean through a channel in the city of Rio Grande (Toldo et al., 2006). The orientation of its longitudinal axis is NE-SW, aligned with the prevailing wind direction of the region, which corroborates the wind effect's importance as a force for its circulation. The relative importance of wind as a driving force increases as the tidal range decreases (Smith, 1978; Lee et al., 1990; Millet et al., 1991; Wong, 1991; Lu \& Wong, 1994), a typical effect of lagoons that have only one connection with the ocean (Kjerfve, 1986; Kjerfve \& Magill, 1989).
Delaney (1965) geomorphologically divided Patos Lagoon into three regions: the estuarine region, situated between the lagoon mouth and Ponta da Feitoria; the central region, representing the area between Ponta da Feitoria and the entrance of Casamento Lagoon; and the upper region, including Casamento Lagoon and Guaíba Lake. This study covers Patos Lagoon's northern area, as shown in Figure 1.

The atmospheric circulation in the region is determined by two types of high-pressure systems (Möller Jr, 1996). The first is an anticyclone over the Atlantic Ocean, which is located at approximately $30^{\circ} \mathrm{S}$. This center acts as a source of hot and humid air masses carried by the northeast wind. Anticyclones of polar origin, which generally move north carrying cold and dry air masses, are the other type of system. The passage of these frontal systems is more frequent during winter, having an average period of 6 days (Stech \& Lorenzzetti, 1992); in summer, the average period is 11 days (Möller Jr, 1996). The prevailing wind regime in the region is northeast, associated with an anticyclone over the Atlantic Ocean. However, in winter, the increased frequency of frontal system passage causes an increase in the frequency of south-quadrant winds (Möller Jr, 1996). The average northeast and southwest wind speeds for the region are between 3 and $5 \mathrm{~m} \mathrm{~s}^{-1}$ (Herz, 1977; Tomazelli, 1993). The northeast wind, acting on the central region of the lagoon, generates southward water transport, which causes a depression in the lagoon body level in the northern part (Itapuã) and an elevation in the southern part (Feitoria). In contrast, Patos Lagoon waters' response to the southeast wind action is opposite to that found under the northeast wind action, with an accumulation of water in Itapuã and depletion in Feitoria (Castelão \& Moller, 2003).

\section{BATHYMETRIC AND WIND DATA}

The bathymetric data of Patos Lagoon were acquired through nautical charts available on the website of the Directorate of Hydrography and Navigation (DHN), which were digitized by the Coastal Engineering Laboratory of the Federal University of Rio Grande (FURG). Pre-existing data from Nicolodi (2013) and the project "Sedimentation of the Guaíba Complex" were also used. 


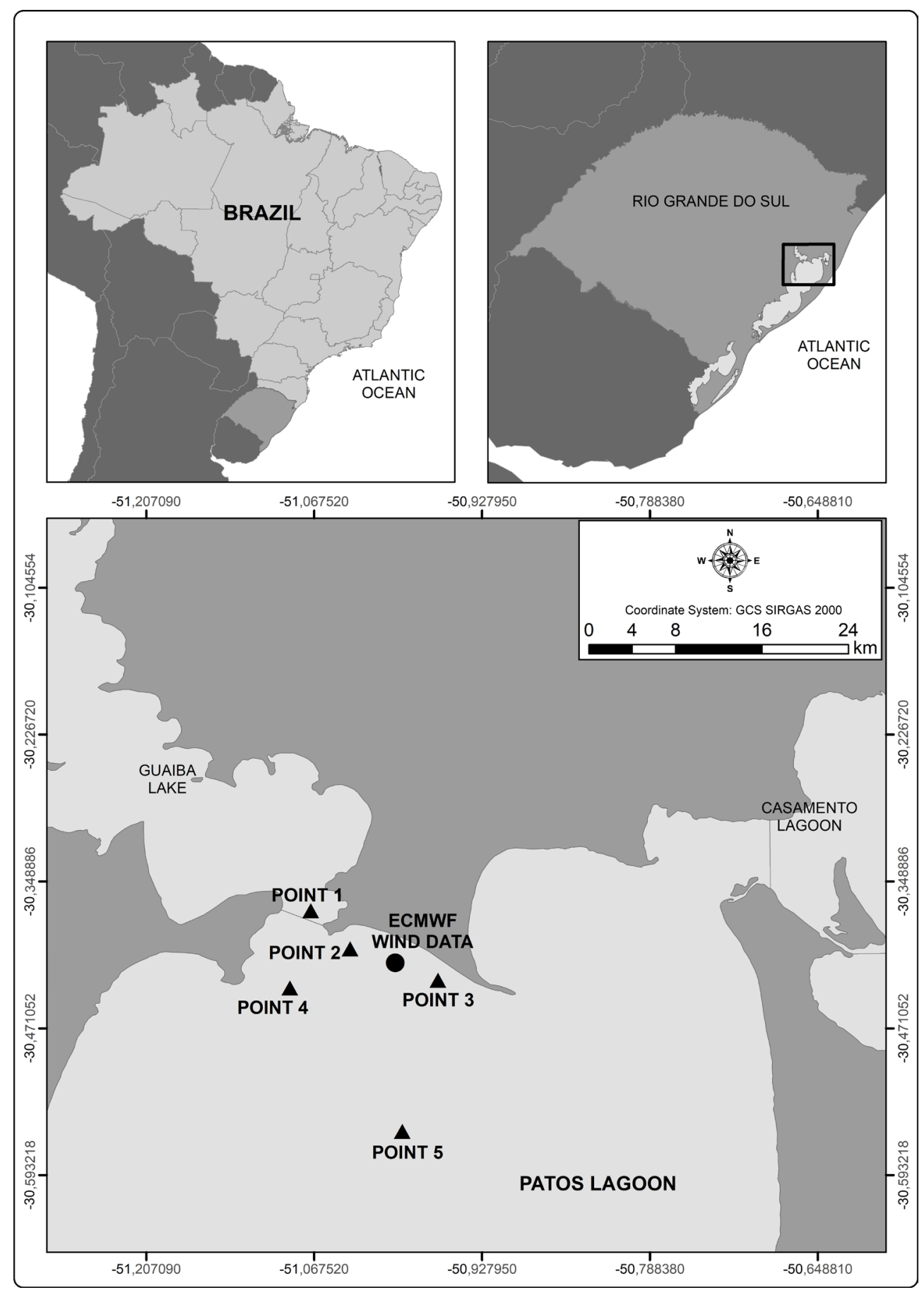

Figure 1. Study area, located in Patos Lagoon (Brazil). Points 1-5 fixed in the model at different depths for the time series extraction. Localization of the time series of wind intensity and direction used in the simulation.

For the wave model to be developed, data on the wind regime and bathymetry of the study region must be previously known and defined. Such factors are used as input data for SWAN, where winds and the local bathymetry induce wave generation.
For calibration and validation of the wave model, a time series of winds from the Rio Grande Pilot Station was used from August 16 to December 31, 2018, which is read every hour, with 16 sectors for wind direction. Because the acquisition of wind intensity 
values is made at $25 \mathrm{~m}$ altitude, it was necessary to reduce them to $10 \mathrm{~m}$ according to Equation 1 (Coastal Engineering Manual - Part II).

$$
u_{z}=u_{z o b s}\left(\frac{z}{z o b s}\right)^{1 / 7} \quad \text { (Equation 1) }
$$

where

$u_{z}$ is the wind speed at new height $z$ and

$\mathrm{u}_{\text {zobs }}$ is the wind speed recorded at the observed height.

For the numerical simulation in the study region, a time series of wind intensity and direction obtained from ECMWF/ERA-Interim reanalysis data was used. This choice took into account the absence of weather stations near the study region. ERAInterim is the latest global atmospheric reanalysis produced by ECMWF, launched in 2009. It has several improvements compared to its predecessors, with a spatial resolution of $0.25^{\circ}$ and hourly temporal resolution. For the development of this work, data for the zonal and southern wind components, at the height of ten meters, were extracted from the coordinate points $51^{\circ} \mathrm{W}$ and $30.25^{\circ} \mathrm{S}$, beginning in December 2017 and for the whole year 2018. It was necessary to calculate the magnitude and direction of winds, a method performed in the SisBAHIA software. A wind rose was constructed for the time series to characterize the $2017 / 2018$ wind regime.

\section{Numerical modeling}

This section describes the methodological steps employed in the present study. The methodology includes the acquisition of bathymetry and wind intensity and direction data, as well as the wave parameters measured in situ by a directional waverider buoy moored in the central region of Patos Lagoon. The wave computational modeling used the following input variables: local bathymetry and wind time series. After calibrating and validating the model, the wave regime in the northern sector of Patos Lagoon for 2017/2018 was characterized by numerical simulation in the Delft3D software. For the time series extraction of wave parameters, including the significant wave height (Hs), peak period (Tp) and propagation direction ( $D p)$, five points at different depths and locations were fixed in the model, with points 1 (UTM 22S $493248.34 \mathrm{mE}, 6639860.0 \mathrm{mN}$ ), 2 (UTM 22S $496394.16 \mathrm{mE}, 6636348.0 \mathrm{mN}$ ), 3 (UTM 22S
$503393.00 \mathrm{mE}, 6633446.0 \mathrm{mN}$ ), 4 (UTM 22S 491750.41 $\mathrm{mE}, 6633217.0 \mathrm{mN}$ ), 5 (UTM 22S $500565.53 \mathrm{mE}$, $6619501.5 \mathrm{mN}$ ) at depths of $3.7 \mathrm{~m}, 5.7 \mathrm{~m}, 5 \mathrm{~m}, 7 \mathrm{~m}$, and $7.5 \mathrm{~m}$, respectively, as shown in Figure 1 .

\section{IN SITU WAVE MEASUREMENTS}

Wave data were acquired through the directional waverider buoy (model DWR-G), designed by the Dutch company Datawell, moored at a distance of approximately $14 \mathrm{~km}$ from the coast of São Lourenço do Sul, on the west bank of Patos Lagoon, at coordinates of $31^{\circ} 29^{\prime} \mathrm{S}$ and $51^{\circ} 55^{\prime} \mathrm{W}$ (Figure 2) and local depth of $6 \mathrm{~m}$. The waverider buoy in the present study belonged to the Federal University of Rio Grande (FURG) and was acquired via the project "Rede Ondas." Its technical characteristics include a diameter of $0.7 \mathrm{~m}$ and a GPS-based wave sensor, which measures wave height, period and direction, and water temperature. This equipment was installed on August $15^{\text {th }}, 2018$, recording and transmitting data to the FURG station at the São Lourenço do Sul Campus with a frequency of 30 minutes. The visualization of the collected data can be performed in real-time with the W@ves21 software, also developed by the company Datawell.

\section{WAVE MODEL}

To simulate wave generation and propagation in Patos Lagoon, the SWAN model was used. This model was developed by the Delft Technological University in the Netherlands. It is a third-generation model used in shallow coastal regions with physical parameters such as refraction, shoaling, wind-wave generation, whitecapped wave breaking, and bottom friction. For the application and calibration of the wave model, the steps below were followed:

- making a rectangular grid with a spatial resolution of 500 meters, which was determined through a procedure called Grid Independent Test (Shin, 2013). This test is performed to eliminate/reduce the influence of the number of grids/grid size on the computational results;

- insertion and interpolation of bathymetric data extracted by scanning available nautical charts and compiling pre-existing data; 


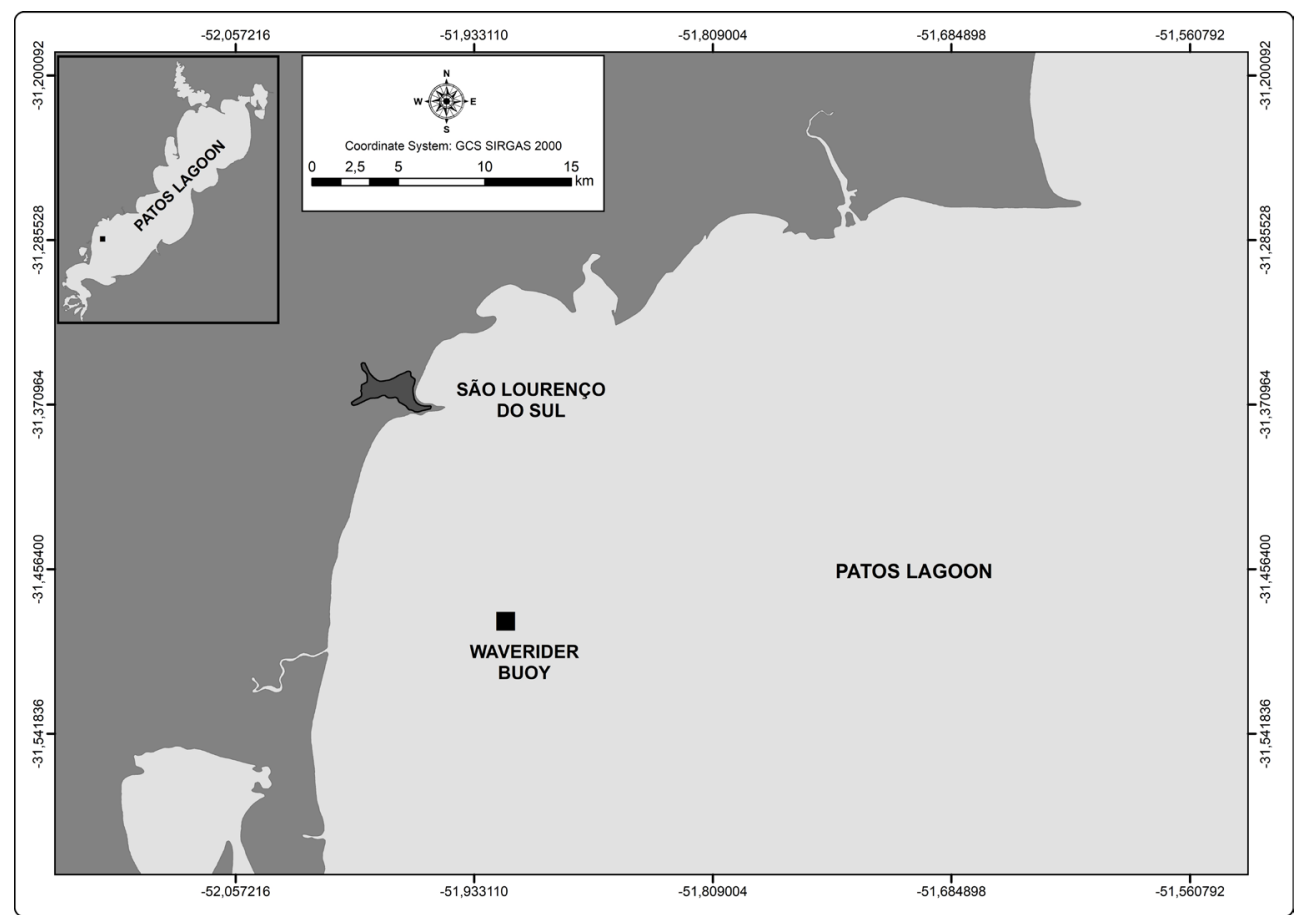

Figure 2. Directional waverider buoy moored in Patos Lagoon.

- wave simulation in the lagoon performed with all contours closed;

- activation of depth-induced breaking, bottom friction, whitecapping, and refraction processes;

- wind shear coefficient (CD) determined by Wu (1982) parameterization (Equation 2);

- Collins bottom friction coefficient 0.030 and whitecapping with Komen formulation (Komen et al., 1984).

$C_{D}=\left(0.80+0.065 \mathrm{~W}_{10}\right) \times 10^{-3}$ (Equation 2)

\section{Wave model validation for Patos Lagoon}

Through hourly wind intensity and direction data, wave generation was simulated using the SWAN model. In the numerical grid used, the point with the same coordinates as the buoy was selected to record significant wave height values, peak period, and propagation direction generated through the modeling, making it possible to perform statistical analysis between modeled wave parameters and wave parameters recorded by the waverider buoy. Both time series of simulated and measured wave parameters were analyzed based on statistical calculations available in the literature (Melo et al., 2008; Lalbeharry, 2001), evaluating the parameters described below.

- Average measured data (ó).

- Averaged modeled data $(m)$.

- Bias (V): determines the average deviation between the results compared; if positive, it tends to overestimate the measurements, and if negative, it understates them.

- Root mean square error (RMSE): indicates the magnitude of the error of the modeled values in relation to the measured values; thus, it is used to evaluate the accuracy of the results.

- Scattering Index (SI): indicates the percentage error of the system as a function of the mean values, representing confidence in the data set.

- Symmetric Slope (SS): a result of a regression analysis where it is considered that neither of the two data sets (observed and modeled) is perfect but contribute equally to the error. In an ideal situation $\mathrm{SS}=1$; if the SS value is different from the ideal situation, the model will be underestimating ( $\mathrm{SS}<1$ ) or overestimating (SS> 1). 


\section{RESULTS AND DISCUSSION}

\section{WIND AND WAVE OBSERVATIONS}

During the period used to perform wave model validation, the highest wind occurrences came from the ENE (15.4\%) and NE (12\%), followed by winds from the $\mathrm{E}(9.7 \%), \mathrm{S}(8.7 \%)$ and SSE (8.6 \%), as shown in Figure 3. Regarding the intensities, the occurrences were as follows: winds from 6 to $9 \mathrm{~m} \mathrm{~s}^{-1}$ with $40.7 \%$ of the cases, winds from 3 to $6 \mathrm{~m} \mathrm{~s}^{-1}$ with $28.8 \%$ of the records, winds from 9 to $12 \mathrm{~m} \mathrm{~s}^{-1}$ with $18.3 \%$, up to $3 \mathrm{~m} \mathrm{~s}^{-1}$ with $7 \%$, winds from 12 to $15 \mathrm{~m} \mathrm{~s}^{-1}$ with $4.4 \%$ and winds from 15 to $18 \mathrm{~m} \mathrm{~s}^{-1}$ with $0.7 \%$. There were no winds above $18 \mathrm{~m} \mathrm{~s}^{-1}$ during this period.

Overall, the highest wind frequency occurred in the ENE direction, with winds ranging from 6 to $9 \mathrm{~m} \mathrm{~s}^{-1}$, accounting for $6.7 \%$ of cases. The highest intensity winds come from the north quadrant, mainly from the ENE and NE directions.

Through data acquired by the waverider buoy moored in Patos Lagoon, it was possible to construct the wave rose for significant wave height $(\mathrm{Hs})$ and peak period (Tp) according to the wave propagation directions. The present study used just one validation point, like other similar studies. Sorensen et al. (2004) developed a model and simulated for the North Sea, parts of the Norwegian Sea, and the Baltic Sea. The results are validated from wave rider buoy and found that the model is better in prediction than which does not use fine mesh. Nicolodi et al. (2013) studied the dynamic and resuspension by waves and sedimentation pattern definition in low

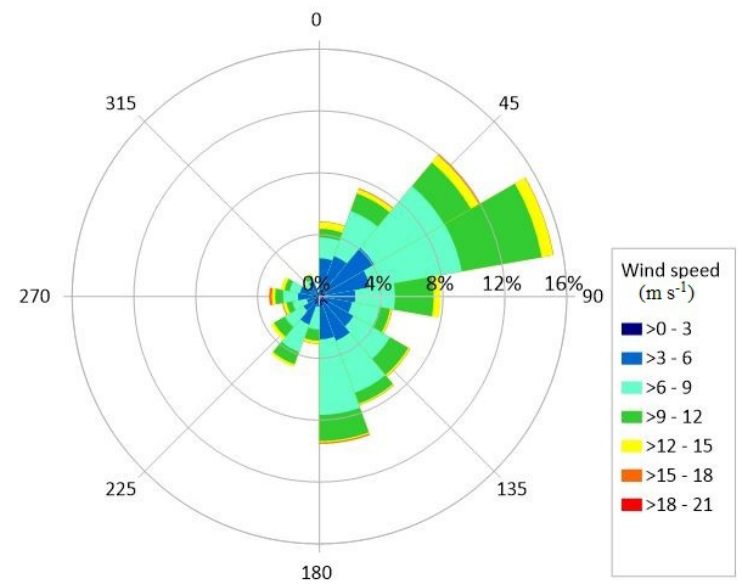

Figure 3. Wind speed and direction, from August 16th to December 31 st 2018, measured at the Rio Grande Pilot Station. energy environments, Guaíba Lake (Brazil), using one validation point. The wave model was validated through a correlation of the data obtained with the data measured by an FSI3D waverider buoy moored near Jangadeiros Club, in the southern area of Porto Alegre (UTM 22S 474233 and 6667179). The results were considered within expectations, and the correlation obtained was comparable to those of most of the studies consulted in the literature and deemed satisfactory.

According to Figure 4, waves from the ENE with $\mathrm{Hs}$ values between 0.3 and $0.6 \mathrm{~m}$ and $\mathrm{Hs}$ values up to $0.3 \mathrm{~m}$ occur most frequently from August to December 2018, totaling $12 \%$ and $10.2 \%$ of cases, respectively. Regarding all directions of propagation, waves up to $0.3 \mathrm{~m}$ occur in $43.7 \%$ of cases, followed by waves between 0.3 and $0.6 \mathrm{~m}$ with $36.6 \%$ of cases, waves between $0.6 \mathrm{~m}$ and $0.9 \mathrm{~m}$ with $17.4 \%$, waves between 0.9 and $1.2 \mathrm{~m}$ with $1.9 \%$ and waves higher than $1.2 \mathrm{~m}$ were only $0.40 \%$ of the entire period.

Regarding the peak period, the highest frequency was found in ENE waves with periods between $3 \mathrm{~s}$ and $4 \mathrm{~s}$, with $13.7 \%$ of the cases, and periods between $2 \mathrm{~s}$ and $3 \mathrm{~s}$ with $11.2 \%$. Overall, peak periods between 3 $\mathrm{s}$ and $4 \mathrm{~s}$ were the most frequent, with $41 \%$ of cases, followed by periods between $2 \mathrm{~s}$ and $3 \mathrm{~s}$ with $37.9 \%$, periods between $1 \mathrm{~s}$ and $2 \mathrm{~s}$ with $12.7 \%$ of cases, periods between $4 \mathrm{~s}$ and $5 \mathrm{~s}$ with $8.3 \%$, and periods between $5 \mathrm{~s}$ and $6 \mathrm{~s}$ with $0.2 \%$ of cases. No waves with periods of less than $1 \mathrm{~s}$ were observed.

\section{Model Validation}

For validation of the wave model, a time series of winds from the Rio Grande Pilot Station was used from August 16 to December 31, 2018, which is read every hour. In general, it is observed that the model reproduces the parameters measured very well. Nevertheless, statistical analysis between the buoy data and the simulated data show a tendency to overestimate the significant wave height and underestimate the peak period and the wave direction of propagation; such characteristics can be observed in Figures 5 and 6.

This trend can be explained by factors such as the lack of detailed bathymetry data, the use of wind data from the atmospheric model, small in situ wave data time series, buoy dimensions, and model-specific settings. This trend was also observed previously in 
(a)

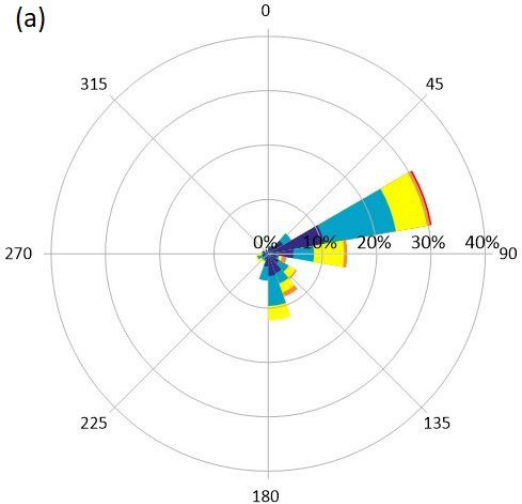

(b)

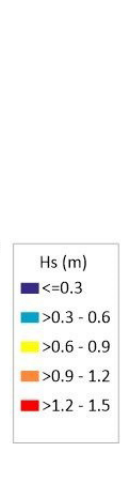

0

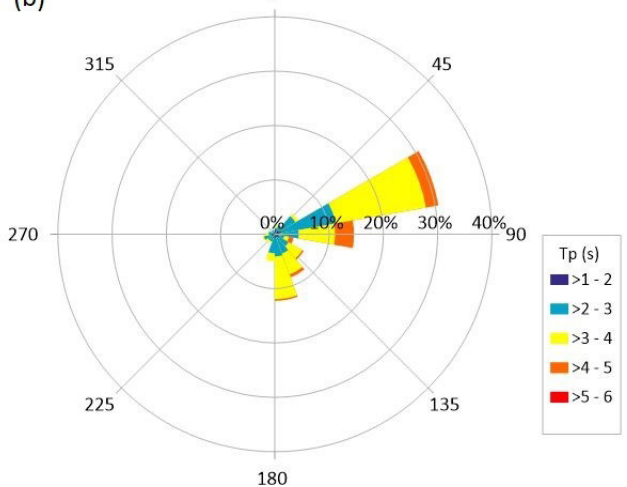

Figure 4. Significant wave height (Hs) (a) and peak period (Tp) (b) according to their propagation direction.
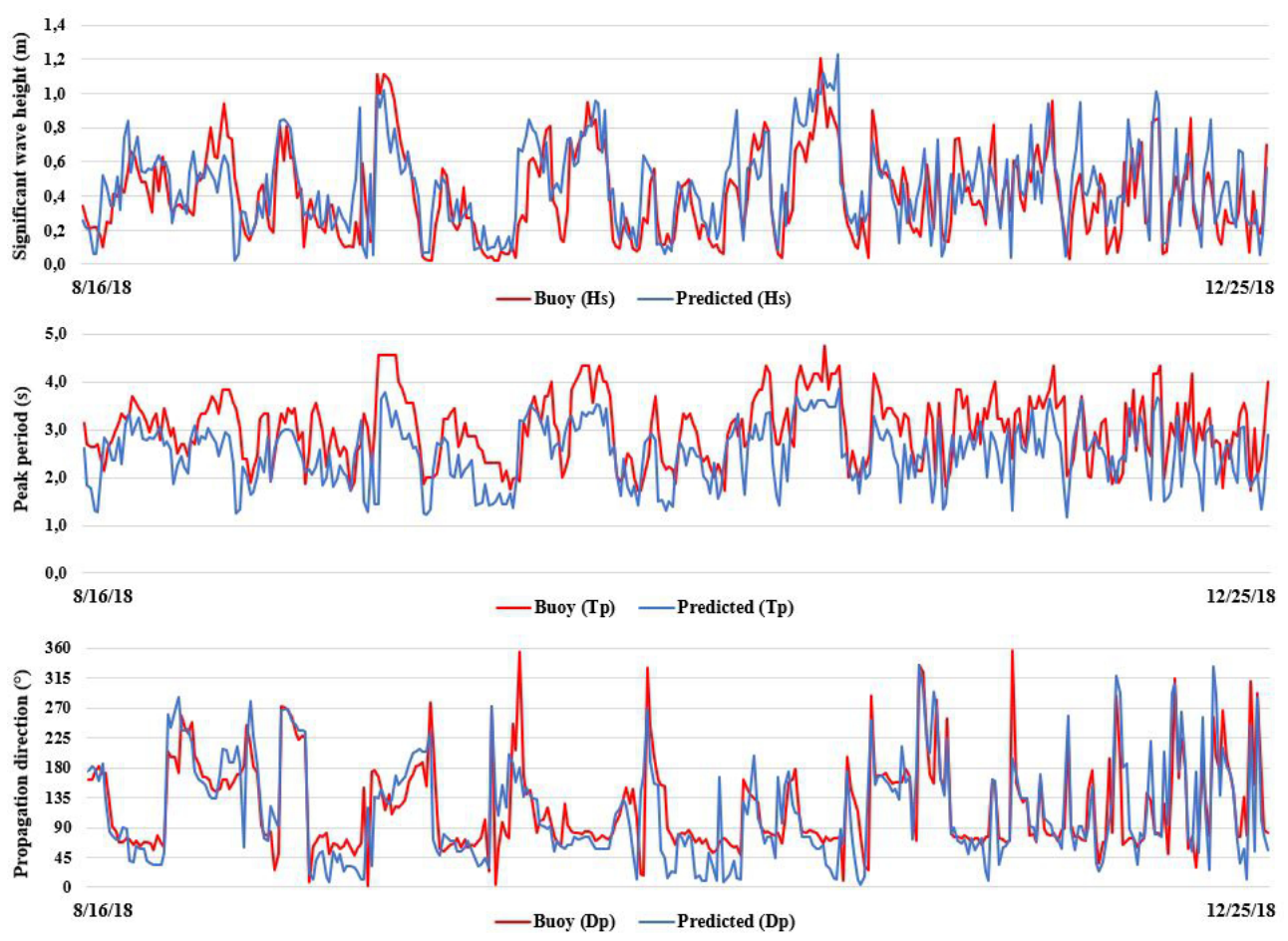

Figure 5. Measured time series (buoy) (red) and modeled time series (blue). a) Significant wave height. b) Peak period. c) Propagation direction.

Lin et al. (2002) and Moeini \& Shahidi (2009), in which the authors applied SWAN in the Chesapeake Bay. Another study also points to this trend in the model, as observed in Rusu et al. (2014). In this article, the authors observed a tendency to underestimate wave height, peak period, and wave propagation direction. The improved Janssen parameterization for the energy transfer from the wind to the waves appears to work better in this study.
Padilla-Hernández \& Monbaliu (2001) compared three different formulations in the SWAN model, for the dissipation of wave energy in shallow locations where wavelength growth is limited by depth. For the Collins formulation, in the SWAN model, the use of a friction bottom coefficient of 0.030 improved the data scattering index (SI), reaching its best values. Hasselman \& Colins (1968) proposed the value of 0.015 for the same coefficient; However, 

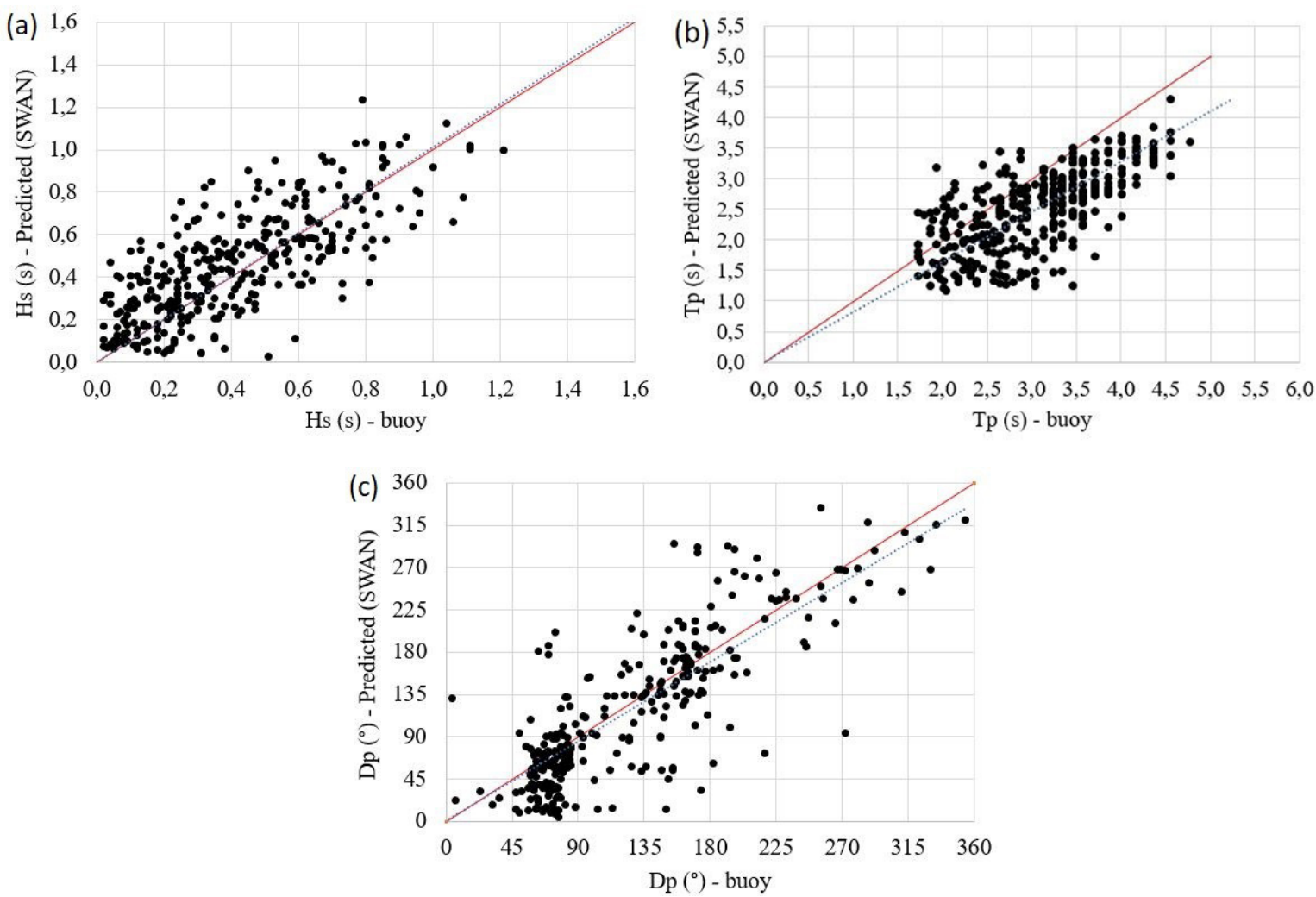

Figure 6. Scatter plots for significant wave height (a), peak period (b), and propagation direction (c). Blue line: Symmetric slope (SS). Red line: Drawn at $45^{\circ}$ for reference.

for the present study, this value worsened the Sl; therefore, the value suggested by Padilla-Hernández \& Monbaliu (2001) was used. Statistical analysis with the two friction coefficients can be observed and compared in Table 1 and Table 2. It is observed that the use of a lower coefficient of friction is responsible for worsening the confidence in the modeled data (SI), increasing the error associated with the process (RMSE), and decreasing data correlation (SS).

As shown in the data, the mean values of significant wave height $(\mathrm{Hs})$, peak period $(\mathrm{Tp})$, and propagation direction (Dp) were $0.44 \mathrm{~m}, 2.59 \mathrm{~s}$ and $107^{\circ}$ for the model and $0.41 \mathrm{~m}, 3.03 \mathrm{~s}$ and $121^{\circ}$ for the waverider buoy measurements, respectively. The SI value was close to $30 \%$, indicating confidence in the numerical simulation. The results indicated an associated mean error (RMSE) of $0.15 \mathrm{~m}$ for $\mathrm{Hs}, 0.76 \mathrm{~s}$ for $\mathrm{Tp}$ and $27.40^{\circ}$ for $\mathrm{Dp}$, as observed in Table 1. This fact contributed to
Table 1. Results of statistical analysis for the coefficient of friction of 0.030 .

\begin{tabular}{lccc}
\hline Parameters & $\mathrm{Hs}(\mathrm{m})$ & $\mathrm{Tp}(\mathrm{s})$ & $\mathrm{Dp}\left(^{\circ}\right)$ \\
\hline Model mean $\left(m^{\prime}\right)$ & 0.44 & 2.59 & 107.00 \\
Buoy mean (ó) & 0.41 & 3.03 & 121.00 \\
V & 0.03 & -0.44 & -14.00 \\
RMSE & 0.15 & 0.76 & 27.40 \\
SI & 0.28 & 0.25 & 0.30 \\
SS & 1.09 & 0.84 & 0.99 \\
\hline
\end{tabular}

significant wave height (Hs); peak period (Tp); propagation direction (Dp).

increased confidence in the data set and decreased error associated with the process.

With the calibrated and validated model, according to the results of the statistical calculations shown in Table 1, a numerical simulation was performed for Patos Lagoon's northern sector. 
Table 2. Results of statistical analysis for the coefficient of friction 0.015 .

\begin{tabular}{lccc}
\hline Parameters & $\mathrm{Hs}(\mathrm{m})$ & $\mathrm{Tp}(\mathrm{s})$ & $\mathrm{Dp}\left(^{\circ}\right)$ \\
\hline Model mean $\left({ }^{\prime}\right)$ & 0.48 & 2.38 & 98.40 \\
Buoy mean $\left(o^{\prime}\right)$ & 0.41 & 3.03 & 121.00 \\
V & 0.07 & -0.65 & -22.60 \\
RMSE & 0.22 & 0.82 & 45.25 \\
SI & 0.56 & 0.28 & 0.47 \\
SS & 1.16 & 0.79 & 0.98 \\
\hline
\end{tabular}

significant wave height $(\mathrm{Hs})$; peak period $(\mathrm{Tp})$; propagation direction (Dp).

\section{Wave modeling in the northern sector of Patos} LAGOON

According to data from ECMWF and after wind magnitude and direction calculations were performed, the annual average wind intensity of $3.8 \mathrm{~m} \mathrm{~s}^{-1}$ was determined. Two peaks of higher wind intensity (above $10 \mathrm{~m} \mathrm{~s}^{-1}$ ) are observed, reaching their maximum value of $10.2 \mathrm{~m} \mathrm{~s}^{-1}$ from the WNW direction on August 8th, 2018, and $10.1 \mathrm{~m} \mathrm{~s}^{-1}$ in the SSW direction on November 24th, 2018. Although these two events recorded magnitudes well above the annual average, they were short events.

Regarding the frequency distribution according to wind intensity classes, winds between 3-6 $\mathrm{m} \mathrm{s}^{-1}$ were the most frequent, with $54.17 \%$, followed by winds between 0-3 $\mathrm{m} \mathrm{s}^{-1}$ with $28.75 \%$, winds between 6-9 $\mathrm{m} \mathrm{s}^{-1}$ with $16.53 \%$, and winds between $9-12 \mathrm{~m} \mathrm{~s}^{-1}$ with only $0.56 \%$. The highest occurrences are associated with winds with velocities of 3-6 $\mathrm{m} \mathrm{s}^{-1}$ in the $E$ direction with $10 \%$, ENE with $9.68 \%$, S with $5.97 \%$, ESE with 5.65\% and, SSE with $5.32 \%$ of the total.

Nicolodi et al. (2011), analyzed the wind data at Salgado Filho airport in Porto Alegre, SE and E winds were the most frequent, with $29 \%$ and $22 \%$, respectively. E winds with $30.08 \%$ of the records, S winds with $13.8 \%$, and SE winds with $12.14 \%$ were observed in the present work. This small difference in patterns can be explained by the distance between the analyzed points and data acquisition because, in those authors' work, the data came from the Aeronautics Command Meteorology Network from 1996, whereas, in the present study, the data come from reanalysis data.

Regarding the seasons, the average wind speed in summer was $3.9 \mathrm{~m} \mathrm{~s}^{-1}$, autumn $3.3 \mathrm{~m} \mathrm{~s}^{-1}$, winter 3.9 $\mathrm{m} \mathrm{s}^{-1}$, and spring $4.2 \mathrm{~m} \mathrm{~s}^{-1}$. From this information, it can be noted that summer, winter, and spring had average wind intensity values above the annual average. Regarding the frequency of occurrence of each wind class, compared with the annual frequency distribution, the only autumn did not show the same pattern of a high occurrence of winds from 3-6 $\mathrm{m} \mathrm{s}^{-1}$. For this season, the highest occurrence was from $0-3 \mathrm{~m} \mathrm{~s}^{-1}$.

According to wind direction, all seasons of the year recorded $\mathrm{E}$ direction as the most frequent, with summer registering $25.5 \%$, autumn $11 \%$, winter $14.8 \%$, and spring $17 \%$. The wind roses for the seasons are shown in Figure 7.

Through the generation and propagation of waves in the study area of the present study, simulated in SWAN from the time series of wind intensity and direction data acquired with the ECMWF reanalysis model, which were discussed in the previous section, we obtained the wave parameters for five points set out in section 2. Below are the results and discussion of the wave parameters according to the four seasons of the year.

\section{SuMmer}

Toldo et al. (2006) acquired significant height and peak period values for specific points in Patos Lagoon in different seasons of the year. At the point nearest to the study region, these values were approximately $0.4 \mathrm{~m}$ and $2.3 \mathrm{~s}$, respectively, in summer. With the modeling performed in the present study, significant height and peak period values for the five points in summer can be observed in Table 3, as well as the mean between the points. The highest value modeled for the points occurred on February $11^{\text {th }}, 2018$, at $17 \mathrm{~h}$, with the following values: $0.77 \mathrm{~m}$ and $2.9 \mathrm{~s}$ for point 1 ; $0.91 \mathrm{~m}$ and $3.3 \mathrm{~s}$ for point $2 ; 0.87 \mathrm{~m}$ and $3.2 \mathrm{~s}$ for point 3; $0.92 \mathrm{~m}$ and $3.3 \mathrm{~s}$ for point 4 and $0.91 \mathrm{~m}$ and $3.3 \mathrm{~s}$ for point 5. On that same day, the maximum value of wind intensity was $9.4 \mathrm{~m} \mathrm{~s}^{-1}$ at $16 \mathrm{~h}$. According to Nicolodi et al. (2011), the waves follow the patterns of intensity and direction of winds, reaching maximum values between 1 and $2 \mathrm{~h}$ after the peak velocities.

Concerning the direction of wave propagation, for points 1 and 2, the highest frequency is associated with ESE waves, followed by $\mathrm{E}$ waves and $\mathrm{S}$ waves. For points 3 and 4, the most frequent waves are from the $E$, followed by ESE and S. Nevertheless, for point 5, the most frequent waves are from the $E$, followed by ENE and ESE. Additionally, it was observed that as the local depth 

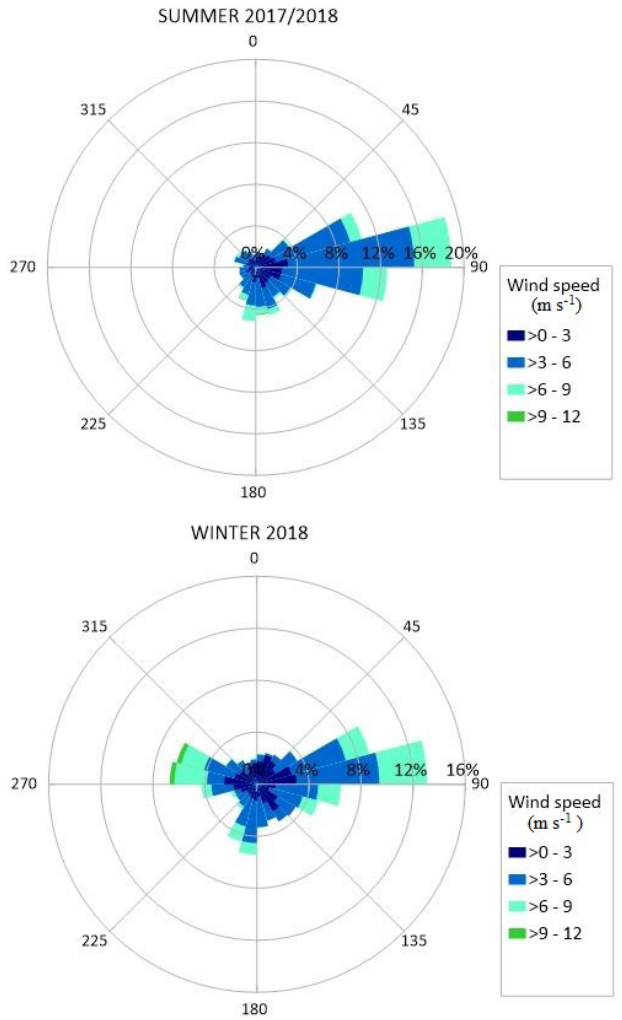
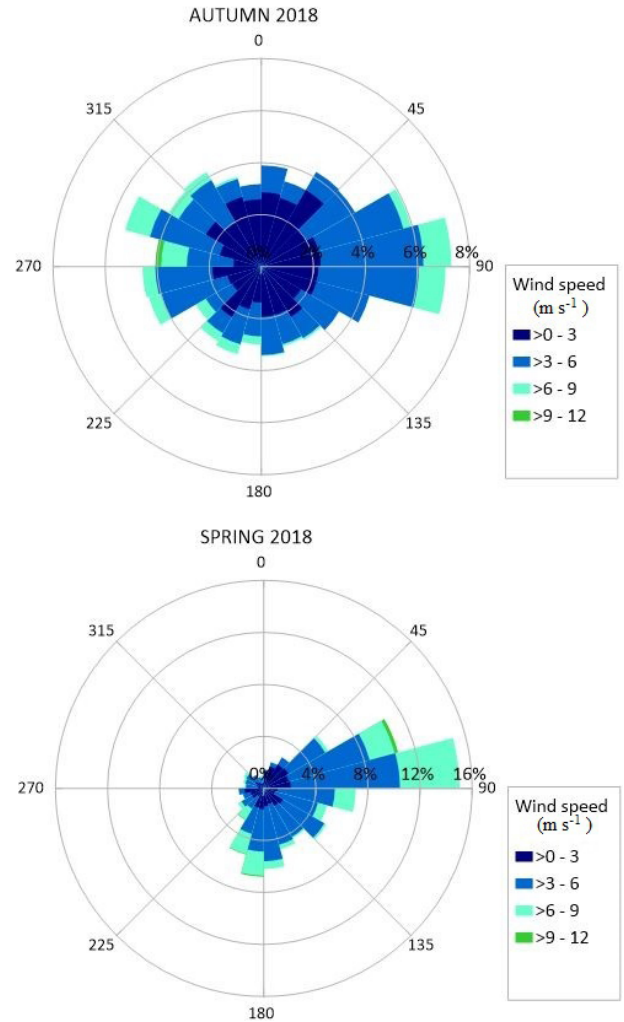

Figure 7. Wind speed and direction for seasons of the year, between December $21^{\text {st }}, 2017$, and December $21^{\text {st }}, 2018$.

Table 3. Depths of points with their significant heights (Hs) and peak periods (Tp) during the 2017/18 austral summer.

\begin{tabular}{lccc}
\hline Points & Depth $(\mathrm{m})$ & $\mathrm{Hs}(\mathrm{m})$ & $\mathrm{Tp}(\mathrm{s})$ \\
\hline 1 & 3.7 & 0.35 & 2.1 \\
2 & 5.0 & 0.40 & 2.2 \\
3 & 5.7 & 0.40 & 2.2 \\
4 & 7.0 & 0.43 & 2.3 \\
5 & 7.5 & 0.45 & 2.4 \\
Mean & 5.8 & 0.40 & 2.2 \\
\hline
\end{tabular}

increases, the frequency of lower heights and shorter periods decreases, increasing the frequency of higher waves. The significant wave height $(\mathrm{Hs})$ and peak period (Tp) occurrence frequency for the 2017/18 austral summer are observed in Figure 8.

\section{Autumn}

The significant height and peak period modeling values, as well as the average between the five modeled points, for this season can be seen in Table 4 . For this season, Toldo et al. (2006) obtained significant height and peak period values of $0.5 \mathrm{~m}$ and $2.7 \mathrm{~s}$, respectively. The highest waves found in autumn were $0.61 \mathrm{~m}$ and $2.6 \mathrm{~s}$ for point $1,0.78 \mathrm{~m}$ and $3.0 \mathrm{~s}$ for point 2 , $0.83 \mathrm{~m}$ and $3.2 \mathrm{~s}$ for point $3,0.75 \mathrm{~m}$ and $2.9 \mathrm{~s}$ for point 4 and $0.87 \mathrm{~m}$ and $3.2 \mathrm{~s}$ for point 5 . All these records took place on May $19^{\text {th }}, 2018$, at $18 \mathrm{~h}$. On that same day, the wind had a progressive increase in intensity, reaching its peak at $17 \mathrm{~h}$ with an intensity of $9 \mathrm{~m} \mathrm{~s}^{-1}$, representing a value well above the average for this time of the year and reflected by the observed wave peaks.

Regarding the direction of propagation, for point 1 , the highest frequencies are associated with ESE waves, followed by SE and SSE waves. For point 2, the highest frequency is in the ESE direction, followed by the $E$ and WSW directions. At point 3, waves are more frequent in the $E$ direction, followed by the ESE and SSW directions. In point 4, the waves more frequently come from the E, ESE and SSW. Finally, at point 5, the most frequent waves also come from the $E$, followed by the ENE and ESE. The significant wave height $(\mathrm{Hs})$ and peak period (Tp) occurrence frequency for the 2018 austral autumn are observed in Figure 9. 


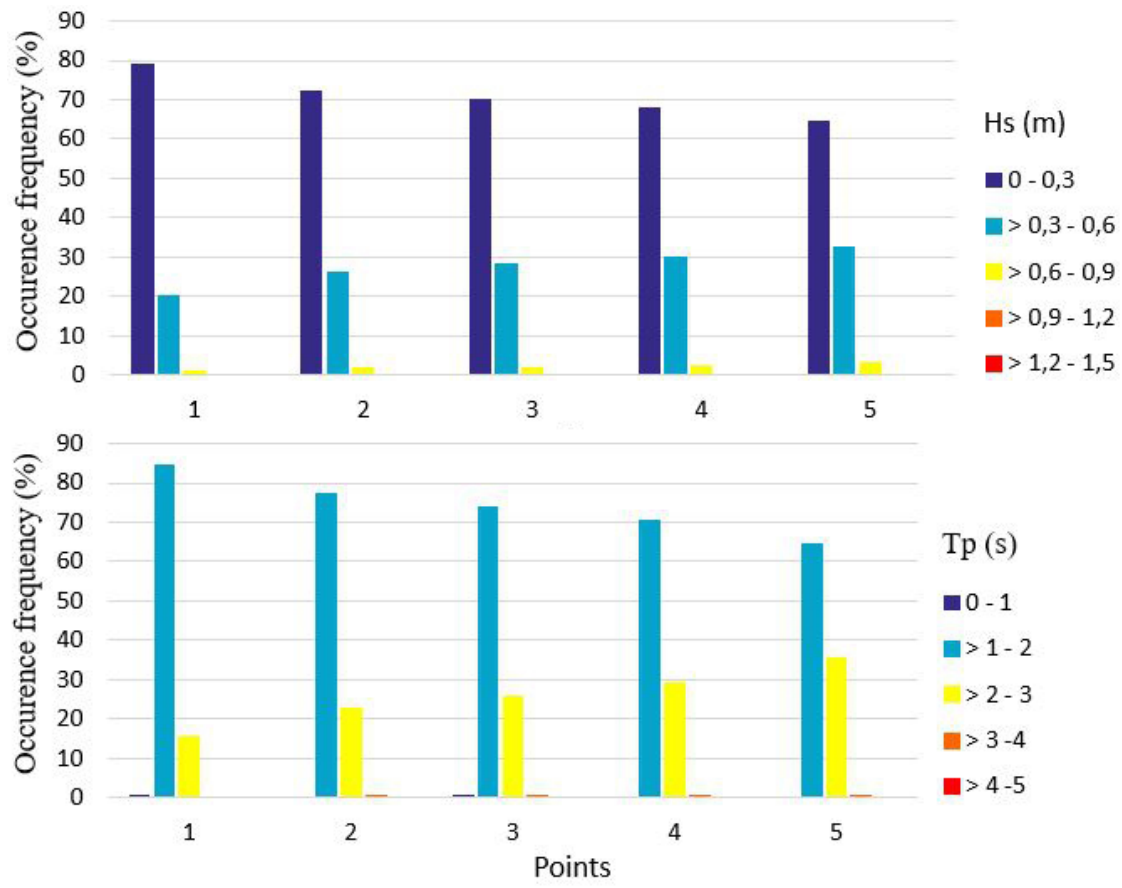

Figure 8. Significant wave height (Hs) and peak period (Tp) occurrence frequency for the $2017 / 18$ austral summer.

Table 4. Depths of points with their significant heights (Hs) and peak periods (Tp) for the 2018 austral autumn.

\begin{tabular}{lccc}
\hline Points & Depth $(\mathrm{m})$ & $\mathrm{Hs}(\mathrm{m})$ & $\mathrm{Tp}(\mathrm{s})$ \\
\hline 1 & 3.7 & 0.32 & 2.0 \\
2 & 5.0 & 0.36 & 2.1 \\
3 & 5.7 & 0.38 & 2.2 \\
4 & 7.0 & 0.38 & 2.2 \\
5 & 7.5 & 0.41 & 2.3 \\
Mean & 5.8 & 0.37 & 2.2 \\
\hline
\end{tabular}

\section{WiNTER}

For the winter period, the largest waves identified for each modeled point were as follows: $0.67 \mathrm{~m}$ and $2.7 \mathrm{~s}$ for point $1 ; 0.81 \mathrm{~m}$ and $3.1 \mathrm{~s}$ for point $2 ; 0.83 \mathrm{~m}$ and $3.2 \mathrm{~s}$ for point $3 ; 0.80 \mathrm{~m}$ and $3.1 \mathrm{~s}$ for point 4 and $0.90 \mathrm{~m}$ and $3.2 \mathrm{~s}$ for point 5 . These highest waves were recorded on August $19^{\text {th }}, 2018$, at $18 \mathrm{~h}$ for points $1,2,3$ and 4 , where the winds reached $8.5 \mathrm{~m} \mathrm{~s}^{-1}$ at $17 \mathrm{~h}$ of the same day. For point 5 , the highest wave recorded was on August $9^{\text {th }}, 2018$, at $17 \mathrm{~h}$, with winds reaching 10.2 $\mathrm{m} \mathrm{s}^{-1}$ at $16 \mathrm{~h}$ on the same day, which were the highest wind intensities for the winter. For this same season, Toldo et al. (2006) obtained a significant height value of $0.5 \mathrm{~m}$ and a peak period of $2.8 \mathrm{~s}$. The average wave parameters analyzed can be seen in Table 5 .
Regarding the direction of wave propagation, for point 1 , the highest wave frequencies are associated with $\mathrm{E}$ waves, followed by SE, ESE, and WNW waves. For point 2, the highest frequency was $E$, followed by ESE and W. This same pattern was verified for points 3 and 4 . Finally, for point 5 , the highest frequency is for waves from the ENE, followed by the $E$ and $W$. The significant wave height $(\mathrm{Hs})$ and peak period ( $\mathrm{Tp}$ ) occurrence frequency for the 2018 austral winter are observed in Figure 10.

\section{SPRING}

During this season, the highest significant heights and peak periods modeled for the five points were 0.76 $\mathrm{m}$ and $2.9 \mathrm{~s}$ at point $1,0.94 \mathrm{~m}$ and $3.3 \mathrm{~s}$ at point $2,0.96$ $\mathrm{m}$ and $3.4 \mathrm{~s}$ at point $3,0.93 \mathrm{~m}$ and $3.3 \mathrm{~s}$ at point 4 and 1.0 $\mathrm{m}$ and $3.4 \mathrm{~s}$ at point 5 . All these records were observed on November 24, 2018, at $5 \mathrm{pm}$. On that same day, at 4 $\mathrm{pm}$, the highest wind intensity for these stations was recorded, with winds approximately $10.1 \mathrm{~m} \mathrm{~s}^{-1}$ blowing from the SSW direction. For spring, Toldo et al. (2006) obtained a significant height value of $0.50 \mathrm{~m}$ and a peak period of $2.8 \mathrm{~s}$. The significant height and peak period values for the 5 points analyzed are shown in Table 6 , as are the mean between them. 

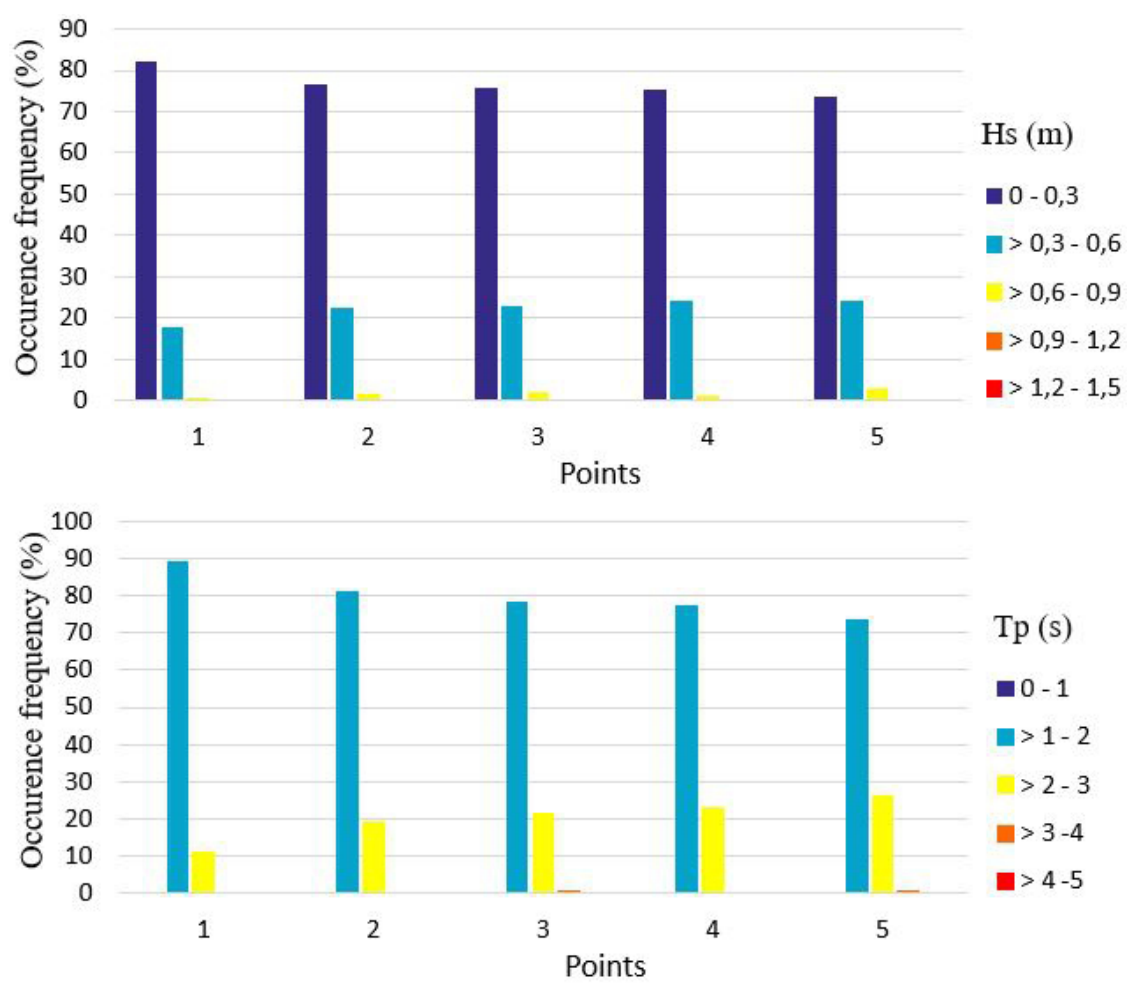

Figure 9. Significant wave height (Hs) and peak period (Tp) occurrence frequency for the 2018 austral autumn.

Table 5. Depths of points with their significant heights $(\mathrm{Hs})$ and peak periods (Tp) for the 2018 austral winter.

\begin{tabular}{lccc}
\hline Points & Depth $(\mathrm{m})$ & $\mathrm{Hs}(\mathrm{m})$ & $\mathrm{Tp}(\mathrm{s})$ \\
\hline 1 & 3.7 & 0.34 & 2.0 \\
2 & 5.0 & 0.40 & 2.2 \\
3 & 5.7 & 0.42 & 2.3 \\
4 & 7.0 & 0.42 & 2.3 \\
5 & 7.5 & 0.47 & 2.4 \\
Mean & 5.8 & 0.41 & 2.2 \\
\hline
\end{tabular}

Regarding the direction of wave propagation, for point 1, the highest frequencies are associated with waves from the $S$, followed by the ESE and SSE. In point 2, the highest frequencies are E, ESE and $S$ waves. For point 3 , the highest frequencies of waves are from the $\mathrm{E}, \mathrm{S}$ and ESE. The same pattern found in point 2 is also observed at point 4. Finally, at point 5 , the highest frequency is associated with the $\mathrm{E}$ direction, followed by the ENE and S directions. The significant wave height $(\mathrm{Hs})$ and peak period $(\mathrm{Tp})$ occurrence frequency in the 2018 austral spring are observed in Figure 11.

\section{WAVE Regime}

According to the data reported in this study, the results are very close to those found by Toldo et al. (2006), even knowing that the points analyzed are not in the same position and depth. The work cited does not present the local depth of each station used to predict the wave parameters so that this fact can explain these small result discrepancies. Moreover, in the study discussed above, the authors did not use waves with heights smaller than $0.10 \mathrm{~m}$ to calculate the significant height and peak period. Another critical factor is the difference in the acquisition of wind data, where the cited reference used measuring stations with anemometers, whereas the present study used reanalysis data. Furthermore, there are differences in the year chosen for modeling because the work described above used the year 1988, and the present study analyzed 2018. Also, according to the validation statistics of the model used in this work, the peak period is underestimated, and differences found between the two studies can be explained. 

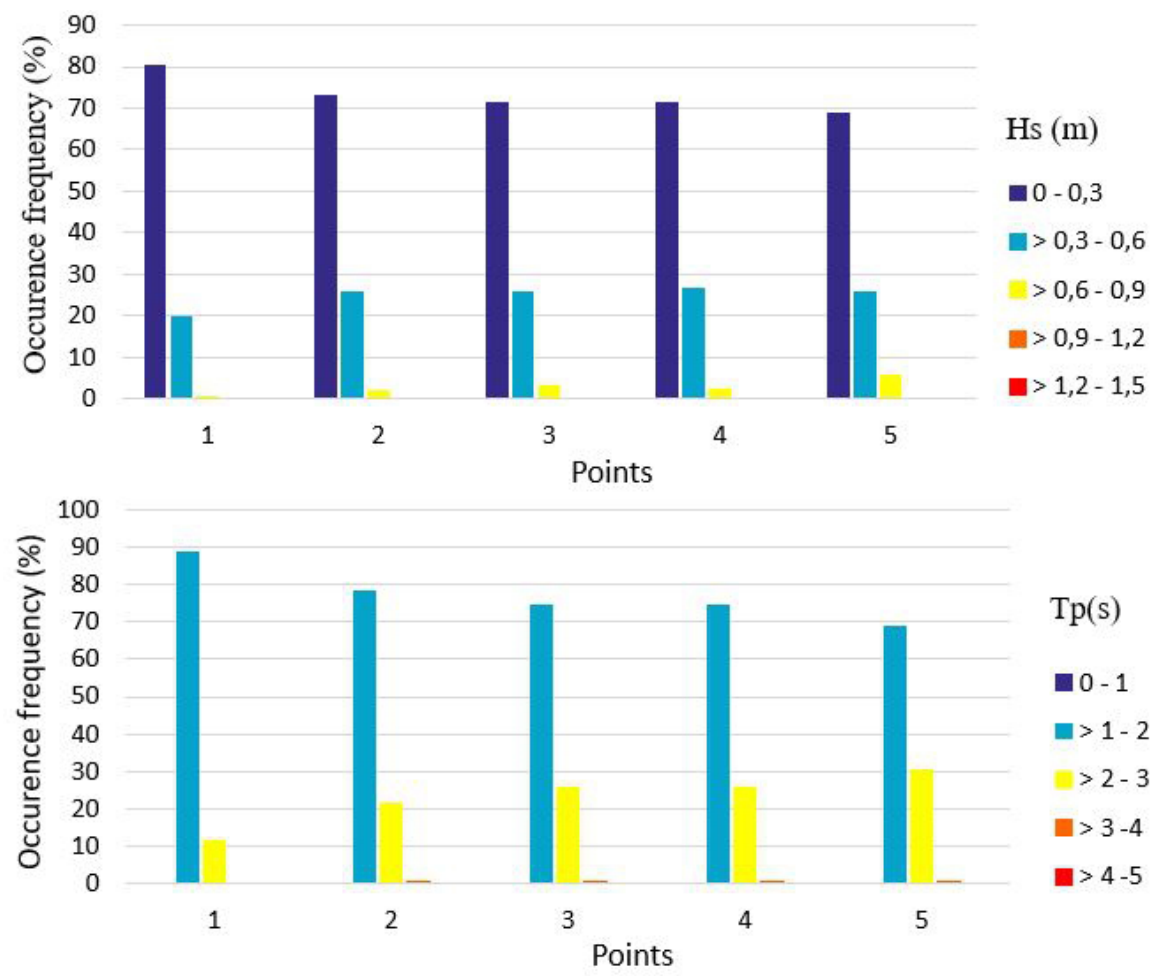

Figure 10. Significant wave height $(\mathrm{Hs})$ and peak period (Tp) occurrence frequency for the 2018 austral winter.

Table 6. Depths of points with their significant heights $(\mathrm{Hs})$ and peak periods (Tp) for the 2018 austral spring.

\begin{tabular}{lccc}
\hline Points & Depth $(\mathrm{m})$ & Mean $\mathrm{Hs}(\mathrm{m})$ & Mean Tp $(\mathrm{s})$ \\
\hline 1 & 3.7 & 0.40 & 2.2 \\
2 & 5.0 & 0.45 & 2.3 \\
3 & 5.7 & 0.45 & 2.3 \\
4 & 7.0 & 0.48 & 2.4 \\
5 & 7.5 & 0.50 & 2.5 \\
Mean & 5.8 & 0.46 & 2.3 \\
\hline
\end{tabular}

There is a direct relationship between the increase in local depth with significant wave height and peak period, a fact found in Lemke et al. (2018) in Patos Lagoon. Nicolodi et al. (2011) consider bathymetry to be a fundamental factor for the whole system because it defines wave patterns.

The results showed that waves with heights up to $0.30 \mathrm{~m}$ represent $77.9 \%$ of the data at point $1,71.3$ $\%$ at point $2,69.7 \%$ at point $3,68.2 \%$ at point 4 and $65.7 \%$ at point 5 . Such a feature was also identified in Lemke et al. (2017), making explicit the increase in larger waves with increasing depth. Seibt et al. (2013) measured waves on Lake Uberlingen at a depth of 2 $\mathrm{m}$ and found that $93 \%$ of waves were less than 0.15 $\mathrm{m}$. The characteristics of this lake imply a smaller wind fetch than Patos Lagoon, thus reducing wave height. Nicolodi et al. (2013), using the SWAN model on Lake Guaíba, resulted in maximum wave height of $0.55 \mathrm{~m}$ under $\mathrm{S}$ and $\mathrm{SE}$ winds at speeds higher than $7 \mathrm{~m} \mathrm{~s}^{-1}$. This small modeled wave height reflects the study site's shallow bathymetry, with significant height values of up to $0.15 \mathrm{~m}$ and peak periods below 3 s. Simão (2016) performed wave modeling near São Lourenço do Sul, in the central part of Patos Lagoon, at a depth of $3 \mathrm{~m}$, based on a 30-year time series of wind intensity and direction data (from 1982 to 2012), and obtained a significant height and peak period of $0.40 \mathrm{~m}$ and $2.5 \mathrm{~s}$, respectively. These values are very close to those found in the present study for point 1 , whose depth is $3.7 \mathrm{~m}$. Although point 1 is located in a deeper region, it is a more sheltered place from the $\mathrm{N}$ and NE winds and is located very close to the coast, having a smaller wind fetch than the study of Simão (2016); this fact may explain the highest significant height and peak period found in work cited. Also, Lemke et al. (2015) modeled waves in the same region of São Lourenço do Sul at a depth of $6 \mathrm{~m}$ and found; as a result, a significant 

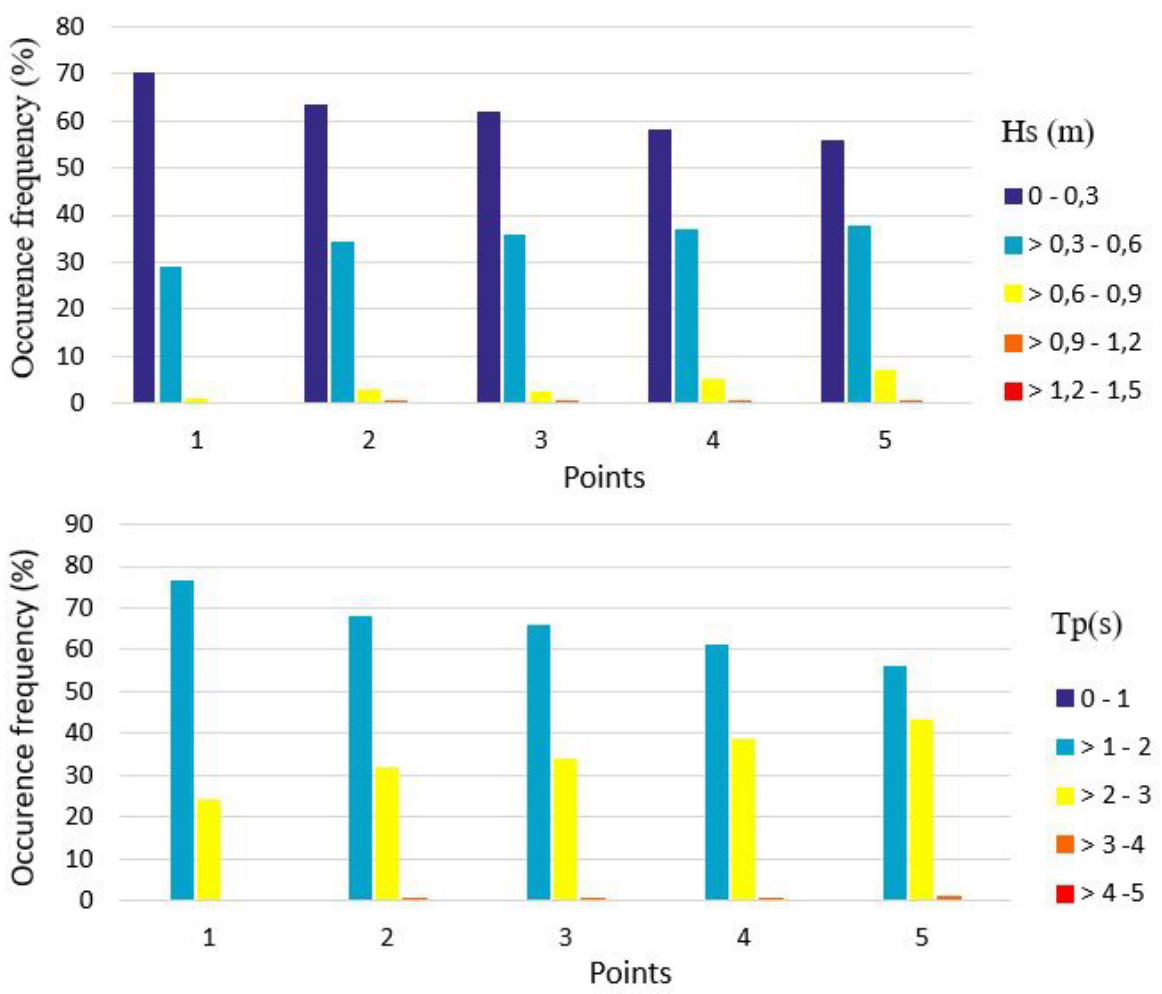

Figure 11. Significant wave height (Hs) and peak period (Tp) occurrence frequency in the 2018 austral spring.

height of $0.57 \mathrm{~m}$ and a peak period of $3.3 \mathrm{~s}$. The more significant local depth explains the higher values. In point 3 of the present study, where the depth is $5.7 \mathrm{~m}$, $\mathrm{Hs}$ and Tp were smaller than those in the other study; this result can be explained by the small wind fetch from the $\mathrm{N}$ and $\mathrm{NE}$ directions, whereas the wind fetch is approximately $70 \mathrm{~km}$ for wind from the $S$ and over $150 \mathrm{~km}$ for wind from the SSW.

In general, the significant height ( $\mathrm{Hs}$ ) and peak period (Tp) values for time series were $0.36 \mathrm{~m}$ and $2.1 \mathrm{~s}$ for point $1 ; 0.40 \mathrm{~m}$ and $2.2 \mathrm{~s}$ for point $2 ; 0.42$ $\mathrm{m}$ and $2.3 \mathrm{~s}$ for point $3 ; 0.43 \mathrm{~m}$ and $2.3 \mathrm{~s}$ for point 4; $0.46 \mathrm{~m}$ and $2.4 \mathrm{~s}$ for point 5 . respectively. Regarding the maximum-modeled height, during the annual time series, the highest values were $1.0 \mathrm{~m}$ and 3.4 $\mathrm{s}$ in spring at the deepest point. The highest wave heights modeled for this period come from the $S$ and SSW directions. Thus, it is found that the wave regime for this region in 2018 corresponds to conditions of a low-energy environment, where the maximum significant height is on the order of $1 \mathrm{~m}$, with peak periods in all cases below $4 \mathrm{~s}$.

Concerning the propagation direction, for point 1 , the ESE waves predominate, followed by the $E$ and $S$ waves. At point 2, the same pattern of the predominance of ESE waves followed by $E$ waves is observed; however, SE waves appear more often than the $S$ waves observed at point 1 . At points 3,4 and 5 , the highest predominance is $E$ waves, followed by ESE waves at points 3 and 4 and ENE waves at point 5. South waves at point 3, ENE waves at point 4, and ESE waves at point 5 are also observed, with lower frequencies.

Observing the variations in the model result between the seasons, little difference in significant wave height $(\mathrm{Hs})$, peak period $(\mathrm{Tp})$, and direction of propagation (Dp) was observed. As wave generation in the study area is strictly dependent on local wind patterns, the highest average of $\mathrm{Hs}$ and $\mathrm{Tp}$, among the five modeled points, was found in the spring. Such a pattern was already expected, given the previous knowledge of the wind patterns for that season. When analyzing the time series of the wind intensity data, the highest value found was $10.1 \mathrm{~m}$ $\mathrm{s}^{-1}$ blowing from the SSW direction. Associated with this value, the highest height of the modeled wave, of $1 \mathrm{~m}$ from the $\mathrm{S}$ direction, was observed. Significant differences between summer and winter were not 
observed; this fact can be explained by the location of the study region being, in a way, sheltered from the $\mathrm{N}$ and $\mathrm{NE}$ quadrant winds. Thus, the wave mostly comes from the E quadrant.

\section{CONCLUSIONS}

This article describes the implementation of forced wave prediction by bathymetry and wind in the northern sector of Patos Lagoon, Rio Grande do Sul, Brazil. From numerical wave modeling with wind reanalysis data, it was possible to characterize the wave regime of the northern sector of Patos Lagoon for the year 2018. Generally, waves follow the patterns of intensity and direction of prevailing winds, reaching their maximum values between 1 and $2 \mathrm{~h}$ after peak wind intensity. Thus, the study region was defined as low energy, with significant small-height waves (between $0.36 \mathrm{~m}$ and $0.46 \mathrm{~m}$ ) with high frequencies and short peak periods (between $2.1 \mathrm{~s}$ and $2.4 \mathrm{~s}$ ); the morphology and small mean depth limit the growth of wind-forced waves. The largest observed waves $(1.0 \mathrm{~m}$ and $3.4 \mathrm{~s})$ from the $\mathrm{S}$ and SSW directions are related to winds with intensities of $10 \mathrm{~m} \mathrm{~s}^{-1}$ from the $S$ direction. The morphology of the shallow lagoon, the orientation of its main axis, and the wind pattern are mostly responsible for these characteristics.

Comparative analysis between the wave parameters measured by the wave buoy and the data obtained through numerical simulation showed good SWAN performance; thus, some factors related to the characteristics defined in the model and the data acquisition mode crucial to achieve the results reported here. Concerning model calibration, the choice of mean wind intensity data and a higher background friction coefficient responded very well to expectations to improve the statistical parameters by bringing the model results and the measured data closer together. The model tended to overestimate wave height and underestimate peak period and wave propagation direction. In the model, the average wave height, mean peak period and mean propagation direction were $0.44 \mathrm{~m}, 2.59 \mathrm{~s}$, and $107^{\circ}$, respectively, while the buoy data had values of 0.41 $\mathrm{m}, 3.03 \mathrm{~s}$, and $121^{\circ}$. respectively. Thus, it could be concluded that the model can be applied in Patos Lagoon, offering meaningful results.
Some experiments can also be performed to improve model validation, such as the use of more refined numerical mesh, which, however, requires higher computational capacity and modeling time; the acquisition of more extensive and more prolonged time series for wave parameters to increase the statistical samples; and the use of wind intensity and direction data acquired through automatic stations near the study region to better understand the representativeness of the reanalysis data for Patos Lagoon. Besides, the present study did not include lagoon level variations and Lake Guaíba flow in the experiment, factors that may be considered in further studies.

Numerical models are a powerful tool for wave regime calculation, helping overcome prediction difficulties due to the random nature of the processes. The present study contributed to the availability of data concerning wave regimes in a specific sector of the lagoon. There are few works developed for this purpose, collaborating with the research and publishing useful information for navigation and coastal engineering, as well as for studies on lagoon dynamics.

The development of this work generates useful information that can contribute to the Conservation Unit's management, which is adjacent to the study area, Itapuã State Park, and the Brazil-Uruguay waterway recovery project. This action has been discussed within the local government and would help balance the region's transport matrix. In this proposal's technical viability study, the main navigable stretches studied are Patos Lagoon and Guaíba Lake, which were the object of this article.

\section{ACKNOWLEDGMENTS}

The authors of this paper are grateful to Deltares for the license to use Delt3D software, the Rio Grande Maritime Pilots and European Centre for Medium-Range Weather Forecasts for providing meteorological and reanalysis data, both crucial for the development of the work, and project "Ondas Network - Shallow Water Wave Monitoring Network". This study was funded by the Brazilian Coordination for the Improvement of Higher Education Personnel (CAPES) through the PhD scholarship to C. Marinho. J. Arigony-Neto acknowledges the Brazilian National Council for Scientific and Technological Development (CNPq) research grant number 205732/2018-6. 


\section{AUTHOR CONTRIBUTIONS}

J.A.N: Conceptualization, Project Administration, Resources, Supervision, Validation, Writing review \& editing

J.L.N: Conceptualization, Funding acquisition, Project Administration, Validation, Resources, Supervision, Writing - review \& editing

N.L: Conceptualization, Formal Analisys, Methodology, Validation, Writing - review \& editing

J.A.S.F: Conceptualization, Resources, Validation, Writing - review \& editing

\section{REFERENCES}

AKPINAR, A., VANVLEDDER, G. P., KÖMÜRCÜ, M. I. \& ÖZGER, M. 2012. Evaluation of the numerical wave model (SWAN) for wave simulation in the Black Sea. Continental Shelf Research, 50-51, 80-99.

BRYANT, E. 1979. Comparison of computed and observed breaker wave heights. Coastal Engineering, 3, 39-50.

CASSIANO, G. F., RIBEIRO, R. B. \& YASSUDA, E. A. 2012. Acquisition of wave data and modeling in Santos Bay, São Paulo, Brazil. In: $10^{\text {th }}$ International Conference on Hydroscience \& Engineering, 4-7 Nov. 2012. Orlando, Flórida, USA: ICHE-2012.

CASTELÃO, R. M. \& MÖLLER, O. O. 2003. Sobre a circulação tridimensional forçada por ventos na Lagoa dos Patos. Revista Atlântica, 25(2), 91-106.

DELANEY, P. 1965. Fisiografia e geologia de superfície da planície costeira do Rio Grande do Sul. DSc. University of São Paulo. Available at: https://teses.usp.br/teses/disponiveis/44/44997/tde-29082016-151600/publico/Delaney_ Doutorado.pdf [Accessed 10 July 2018].

ECMWF (European Centre for Medium-Range Weather Forecasts). ERA Interim, Daily [online]. Reading, UK: ECMWF. Available at: https://apps.ecmwf.int/datasets/data/interim-full-daily/levtype $=\mathrm{sfc} /$ [Accessed: 14 January 2019].

FONTOURA, J. A. S., NICOLODI, J. L., ROMEU, M. A. R., MELO, E., LEMKE, N., AGUIAR, D. F. \& GOULART, M. M. 2015. Medição direcional de ondas na Lagoa dos Patos, RS, Brasil. In: Congresso Hidroviário da Sociedade Brasileira de Engenharia Naval (SOBENA), 6-8 Oct. 2015. Manaus, AM, Brazil: SOBENA.

GUEDES-SOARES, C. 1986. Calibration of visual observations of wave period. Ocean Engineering, 13(6), 539-547.

GUIMARÃES, P.V., FARINA, L., TOLDO JUNIOR, E., DIAZ-HERNANDEZ, G. \& AKHMATSKAYA, E. 2015. Numerical simulation of extreme wave runup during storms events in Tramandaí Beach, Rio Grande do Sul, Brazil. Coastal Engineering, 95, 171-180.

HASSELMANN, K. \& COLLINS, J. I. 1968. Spectral dissipation of finite depth gravity waves due to turbulent bottom friction. Journal of Marine Research, 26(1), 1-12.

HOLTHUIJSEN, L. H. 2007. Waves in oceanic and coastal waters. New York: Cambridge University Press.

JARDINE, T. P. 1979. The reliability of visually observed wave heights. Coastal Engineering, 3, 33-38.
KJERFVE, B. 1986. Comparative oceanography of coastal lagoons. In:WOLFE, D. A. (ed.). Estuarine variability. New York: Academic Press, 63-81.

KJERFVE, B. \& MAGILL, K. E. 1989. Geographic and hydrographic characteristics of shallow coastal lagoons. Marine Geology, 88(3-4), 187-199.

KOMEN, G. J., HASSELMANN, S. \& HASSELMANN, K. 1984. On the existence of a fully developed wind-sea spectrum. Journal of Physical Oceanography, 14(8), 1271-1285.

LALBEHARRY, R. 2001. Evaluation of the CMC regional wave forecasting system against buoy data. Atmosphere-Ocean, 40(1), 1-20.

LEE, J. M., WISEMAN JUNIOR, W. J. \& KELLY, F. J. 1990. Barotropic, subtidal exchange between Calcasieu Lake and the Gulf of Mexico. Estuaries, 13(3), 258-264.

LEMKE, N., FONTOURA, J. A. S., CALLIARI, L. J., AGUIAR, D. F., MELO, E., NICOLODI, J. L., ROMEU, M. A. R. \& GOULART, M. M. 2015. Estudo comparativo entre modelagem e medições de ondas na Lagoa dos Patos - RS, Brasil. In: XI Simpósio sobre Ondas, Marés, Engenharia Oceânica e Oceanografia por Satélite (XI OMARSAT). Arraial do Cabo, RJ, Brazil: Instituto de Estudos do Mar Almirante Paulo Moreira.

LEMKE, N., CALLIARI, L. J., FONTOURA, J. A. S. \& AGUIAR, D. F. 2017. Wave directional measurement in Patos Lagoon, RS, Brazil. Brazilian Journal of Water Resources, 22, e.1.

LEMKE, N., FONTOURA, J. A. S., CALLIARI, L. J. \& FERREIRA, N. M. 2018. Estimativa de cenários característicos de ondas na enseada de São Lourenço do Sul, Lagoa dos Patos - RS. Revista Perspectivas Online: Exatas \& Engenharias, 8(20), 25-42.

LIN, W. Q., SANFORD, L. P. \& SUTTLES, S. E. 2002. Wave measurement and modeling in Chesapeake bay. Continental Shelf Research, 22, 18-19.

LU, X. \& WONG, K. C. 1994. The subtidal lagrangian current in Delaware's inland bays under low wind conditions. Estuarine Coastal and Shelf Science, 39, 353-365.

MATOS, M. F. A., SCUDELARI, A. C., AMARO, V. E. \& FORTES, C. J. E. M. 2017. Integration among numeric Simulating (SWAN) and field data on wave climate determination at the state of Rio Grande do Norte northern coast. Revista Brasileira de Geomorfologia, 18(2), 311-328.

MELO, E., HAMMES, G. R., FRANCO, D. \& ROMEU, A. R. 2008. Aferição do desempenho do modelo WW3 em Santa Catarina. In: III Seminário e Workshop em Engenharia Oceânica - FURG (SEMENGO), 5-7 Nov. 2008. Rio Grande, RS, Brazil: SEMENGO.

MILLET, B., TEXIER, H. \& COLLEUIL, B. 1991. Modélisation numérique de circulation et dynamique sédimentaire d'um écosystème lagunaire tropical: le lac Nokoue (Benin). Journal of Reach Oceanore, 16, 10-15.

MOEINI, M. H. \& ETEMAD-SHAHIDI, A. 2009. Wave parameter hindcasting in a lake using the SWAN model. Scientia Iranica. Sharif University of Technology. Scientia Iranica, International Journal of Science \& Technology, 16(2), 156-164.

NICOLODI, J. L. \& PETTERMANN, R. M. 2011. Vulnerability of the Brazilian coastal zone in its environmental, social and technological aspects. Journal of Coastal Research, S164, 1372-1379.

NICOLODI, J. L., TOLDO JUNIOR, E. E. \& FARINA, L. 2011. Wave dynamics and resuspension in Lake Guaíba (Brazil) with implications on points of water abstraction for human supply. Journal of Coastal Research, SI64, 1550-1554. 
NICOLODI, J. L., TOLDO JUNIOR, E. E. \& FARINA, L. 2013. Dynamic and resuspension by waves and sedimentation pattern definition in low energy environments, Guaíba Lake, Brazil. Brazilian Journal of Oceanography, 61(1), 55-64.

PADILLA-HERNÁNDEZ, R. \& MONBALIUR, J. 2001. Energy balance of wind waves as a function of the bottom friction formulation. Coastal Engineering, 43(2), 131-148.

PAES-LEME, R. B., VIOLANTE-CARVALHO, N., ACCETTA, D. \& MEIRELLES, S. 2008. Modelagem física e computacional de ondas geradas pelo vento em um terminal portuário: o desempenho do modelo SWAN 40.51 em uma região com elevada reflexão e difração. Revista Brasileira de Geofísica, 26(1), 45-59.

PALLARES, E., SÁNCHEZ-ARCILLA, A. \& ESPINO, M. 2014. Wave energy balance in wave models (SWAN) for semi-enclosed domains - Application to Catalan coast. Continental Shelf Research, 87, 41-53.

PLANT, N. G. \& GRIGGS, G. B. 1992. Comparison of visual observations of wave height and period to measurements made by an offshore slope array. Journal of Coastal Research, 8(4), 957-965.

ROCHA, M. V. L., MOURA, T., FORTES, C. J. E. M., CAPITÃO, R., BEZERRA, M. M. \& SANCHO, F. E. 2012. Análise comparativa de medições in situ e estimativas numérica na Praia da Cornélia, Costa da Caparica, Portugal. Journal of Integrated Coastal Zone Management, 12(2), 147-157.

RODRÍGUEZ, M. G., NICOLODI, J. L., GUTIÉRREZ, O. M., LOSADA, V. C. \& HERMOSA, A.E. 2018. Brazilian coastal processes: wind, wave climate and sea level. In: SHORT, A. D. \& KLEIN, A. H. F. (eds.). Brazilian Beach Systems. Switzerland: Springer Nature, pp. 37-66.

RUSU, E. 2016. Reliability and applications on the numerical wave predictions in the Black Sea. Frontiers in Marine Science, 3, 95.

RUSU, L., BERNARDINHO, M. \& SOARES, C. G. 2014. Wind and wave modeling in the Black Sea. Journal of Operational Oceanography, 7(1), 5-20.

SÁNCHES, A. S., RODRIGUES, D. A., FONTES, R. M., MARTINS, M. F., KALID, R. A. \& TORRES, E. A. 2018. Wave resource characterization through in-situ measurement followed by artificial neural networks' modeling. Renewable Energy, 115, 1055-1066.
SEIBT, C., PEETERS, F., GRAF, M., SPRENGER, M. \& HOFMANN, H. 2013. Modeling wind waves and wave exposure of nearshore zones in medium-sized lakes. Limnology and Oceanography, 58(1), 23-26.

SHIN, S. 2013. Simulation of two-dimensional internal waves generated by a translating and pitching foil. Ocean Engineering, 70, 77-86.

SIMÃO, C. E. 2016. Estudo do padrão de ondulações na Lagoa dos Patos utilizando o modelo SWAN (Delft3D), RS, Brasil. MSc. Federal University of Rio Grande.

SMITH, N. P. 1978. Long period, estuarine-shelf exchanges in response to meteorological forcing. In: Nihoul, J. C. J. (ed.). Hydrodynamics of estuaries and Fjords. Amsterdam: Elsevier Oceanography Series 30, pp. 147-159.

SORENSEN, O., KOFOED-HANSEN, H., RUGBJERG, M. \& SORENSEN, L. S. 2004. A third-generation spectral wave model using an unstructured finite volume technique. In: $29^{\text {th }}$ International Conference on Coastal Engineering (ICCE), 19-24 Sep. 2004. Lisbon, Portugal: ICCE.

STECH, J. L. \& LORENZZETTI, J. A. 1992. The response of the South Brazil Bight to the passage of wintertime cold fronts. Journal of Geophysics Research, 97(C6), 9507-9520.

TOLDO, E. E., ALMEIDA, L. E. S. B., CORRÊS, I. C. S., FERREIRA, E. R. \& GRUBER, N. L. S. 2006. Wave prediction along Lagoa dos Patos Coastline, Southern Brasil. Revista Atlântica, 28(2), 87-95.

TOMAZELLI, L. J. 1993. O regime dos ventos e a taxa de migração das dunas eólicas costeiras do Rio Grande do Sul, Brasil. Pesquisas, 20:18-26.

USACE (U.S. Army Corps of Engineers). 2002. Department of the Army. Engineer Manuals. Coastal Engineering Manual - Part II. Washington, DC: USACE.

VAN VLEDDER, G. P. \& AKPINAR, A. 2015. Wave model predictions in the Black Sea: sensitivity to wind fields. Applied Ocean Research, 53, 161-178.

VILLWOCK, J.A., TOMAZELLI, L.J., LOSS, E.L., DEHNHARDT, E.A., HORN Fo, N.O., BACHI, F.A., DEHNHARDT, BA. 1986. Geology of the Rio Grande do Sul Coastal Province. In: RABASA, J., (ed.), Quaternary of South America and Antarctic Peninsula. Rotterdam: A.A. Balkema Publishers, 4, 11p.

WONG, K. C. 1991. The effect of coastal sea level forcing on Indian River Bay and Rehoboth Bay, Delaware. Estuarine, Coastal and Shelf Science, 32(3), 213-229. 